\title{
INCLUSION EDUCATION: LEARNING READING ARABIC LANGUAGE AND ALQURAN FOR BLIND
}

\author{
Rubini, Cahya Edi Setyawan \\ STAI Masjid Syuhada Yogyakarta \\ E-mail: rubinihr80@gmail.com, cahya.edi24@ gmail.com
}

\begin{abstract}
Inclusive education is one of the priorities that must be considered for the sake of equality in educating the nation. Inclusive education is contained in the form of learning towards a group of people with special needs. Special needs in Indonesia are mostly those who have physical disabilities, one of the blind. This study aims to determine how the stages of learning to read Arabic letters and the Qur'an for the blind. This type of research is library research, with the method of collecting data, searching, analyzing, and synthesizing the latest research. The results of the study stages of learning to read Arabic letters and the Qur'an for the blind are: memorize Arabic Braille numeric codes from Alif أ to Ya , memorizing Arabic punctuation, practice fingering Braille hijaiyah letters and Arabic punctuation, IQRA reading practice starting from words to simple sentences, and practice reading the Koran which starts from short letters to long letters.
\end{abstract}

Keywords: inclusive education, Arabic literacy, visual impairment, blind people

\section{INTRODUCTION}

Inclusive Education in Indonesia is regulated in law number 20 of 2003 concerning the education system, which states that every citizen has the same right to obtain a quality education. In the 1945 Constitution, Article 32, paragraphs 1 and 2 also regulates, which emphasizes the right to education for citizens for primary school and is funded by the government. In basic education, the presence of inclusive education includes children with special needs (ABK) learning with normal children, but that has not been implemented and adequately handled. The curriculum must be adapted to different classes with unique and unique ABK characteristics. The teacher is not ready to handle the children in the class with different characteristics.

The principle of inclusive education was adopted at the "World Conference on Special Needs Education: Access and Quality" and restated at the World Education- 
Forum. ${ }^{1}$ The idea of inclusion was further supported by the United Nations Standard Rules on Equal Opportunities for Persons with Disabilities, which state Participation and equality for all. Inclusive education is defined as the process of overcoming the diverse needs of all learners by reducing barriers and in the learning environment. This inclusive education means attending classes according to the child's local school age, with individually designed support. ${ }^{2}$ Inclusive education is the process of strengthening the capacity of the education system to reach all students.

In inclusive education, students with special needs are very diverse in types; one of them is blind. Blind is a condition of the child whose sense of sight or eyes do not function as a channel to receive information in daily activities as a person is alert. ${ }^{3}$ The blind has not yet received much education access. Based on data from the Ministry of Education and Culture, the number of children with disabilities, including visually impaired, in 2016 that only had access to education reached 12 percent. Meanwhile, 88 percent have not had access to education at all. This reality was revealed by the General Chairperson of the Indonesian Blind Association (Pertuni) Aria Indrawati, in the event of the Socialization and Training on the use of E-Pub books for blind people in collaboration with Pertuni and Damandiri Foundation, and the Mitra Mitra Netra Foundation at UIN Sunan Kalijaga Yogyakarta on April 29, 2017. The majority of blind people in Indonesia so far have not had access to obtain knowledge from reading books. ${ }^{4}$

Efforts to ground the Arabic language were carried out by the Ministry of Religion through reading and writing the Quran, and data collection was carried out throughout Indonesia, namely in 12 institutions/foundations spread across 12 regions outside of Java, namely Homes in Aceh, Aceh, PTSN High Cliffs in North Sumatra, the Rehabilitation of People with Visual Disabilities (East Java), PRPCN in Palembang, South Sumatera, Noble Charitable Foundation in Bengkulu, and the Foundation for the Assistance of Special Education for the Blind (YPPLB-A) of West Sumatra. Then the Social Rehabilitation Of People With Visual Impairments (PRSPCTN) Lampung, Social

\footnotetext{
${ }^{1}$ JD Singh, "Inclusive Education In India - Concept, Need And Challenges", An International Peer Reveiwed and refered, Scholarly Research Journal For Humanity Science and English Language (SRJIS), DEC-JAN, 2016, VOL. 3, P. 3224.

${ }^{2}$ UNICEF, Promoting the Rights of Children with Disabilities.Innocenti Research Centre, 2007. Retrieved from http://www.unicef-irc.org/publications/pdf/digest13-disability.pdf on September 2019.

${ }^{3}$ Sutjihati Soemantri, Psikologi Anak Luar Biasa, (Bandung: Rafika Adittama, 2007), p. 65.

4 https://www.cendananews.com/2017/04/juta-tuna-netra-di-indonesia-belum-dapat-aksespend Pendidikan.html, accessed on 3 September 2019 at 11:00.
} 
Institutions For The Blinds of Tabanan Bali, the YPTN-A Foundation of West Nusa Tenggara, East Nusa Tenggara, the Foundation for the Development of the Blind Indonesia (YAPTI) in South Sulawesi, Sekolah Luar Biasa ABCD Muhammadiyah Palu Central Sulawesi, Ar-Rahmah Foundation Pontianak West Kalimantan, and PSBN Fajar Harapan South Kalimantan. In this article, we will discuss inclusive education, the blind, and learning to read Arabic letters and the Koran for the blind.

Arabic letters and the Quran Braille significant developments. In several articles, it is mentioned that the Braille Quran appeared in Indonesia in 1954 when the Indonesian Braille Library Publishing Institute (LPPBI) received Al-Quran submissions from UNESCO. LPBBI is an institution under the auspices of the Ministry of Social Affairs and is domiciled in Bandung. ${ }^{5}$ UNESCO is a distributor of the Braille Al-Quran, which was published by the State of Jordan in 1952. UNESCO played an essential role in the development of the use of the Braille Ara Letter as well as its standardization for the blind. In 1956 A. Arif, an official at the Ministry of Social Affairs, took the initiative to bring the Koran Braille to Yogyakarta and handed over to Supardi Abdul Shomad, a blind person who worked as a typist in his office. ${ }^{6}$ He graduated from Yogyakarta Krapyak boarding school. Supardi was assisted by two of his friends, namely Darma Pakilan, an IAIN student from Sunan Kalijaga from Sulawesi, and Fuad Aziz, a lecturer at the Adab Faculty of UIN Sunan Kalijaga Yogyakarta. Supardi began experimenting with reading the Braille Koran. Finally, he succeeded in reading the Surah for the first time, Surah Yasin. For the first time, the experiment was taught to a BPPS blind blind student from Riau named Wardinah Noor. In a short period, all verses in the Jordan Braile Quran manuscript volume VI Finally can be read. ${ }^{7}$

The success of Supardi and some of his friends in uncovering the writing system in the Quran Braille Jordan is a monumental achievement, as well as opening new hopes

\footnotetext{
${ }^{5}$ H.R Rasikhin, "Looking for the Braille Arabic Letter Formulation for Writing Braille Al-Quran That Is Closest to the Writing of Al-Quran Awas", in the Documentation of the Third Work Conference of Braille Al-Quran Ulama, (Jakarta: Department of Religion RI, 1977), p. 11.

${ }^{6}$ This historical data was revealed when Fuadi Aziz conducted an interview with A. Arif, who was then serving as Director at the Directorate of Welfare and Rehabilitation of People with Disabilities of the Indonesian Ministry of Social Affairs. See: Fuadi Aziz. "History of the Writing of Al-Quran Braille in Indonesia", Pryek was delivered to Muker IV of the Braille Ulema on March 15-16, 1978 at Ciawi Bogor. See: Research Center for Religious Literature, Religion Research and Development Agency. Results of the Fourth Deliberation of Al-Quran Ulama Work, Jakarta: Ministry of Religion of the Republic of Indonesia, 1978 , p. 35.

${ }^{7}$ Fuadi Aziz, "Sejarah Penulisan Al-Quran Braille di Indonesia”, p. 36.
} 
for blind Indonesian Muslims towards the renewal of the learning methods of Arabic letters and the Koran which previously relied on the Sima'i method (listening to others), with the presence of the Braille system, then switched to the reading (Qiraah) and writing (Kitabah) methods. This Braille system has proven to be able to make Muslim blind people more independent in reading the Quran. This system was the initial milestone in learning Arabic and Braille Quran. We, as a guardian, should at least know how the Braille Arabic letters use the numeric code, then how is the reading process, including reading the Braille Quran. From there, we as alert people can feel that the dynamics of blind people reading Arabic letters and the Quran is not as easy as we feel.

Previous studies have examined the technology of braille Quran, braille codes, the history of the Quran and Braille Manuscripts, and their development. Based on the results of observations made by the author, have not found research about how the stages in learning to read Arabic letters and the Quran for the blind, because this research is significant so that more and more people with visual impairments can read Arabic letters and the Quran by using braille letters.

\section{RESEARCH METHODS}

This type of research is a library research or literature research through document analysis in the form of a literature study. The data collection technique in this research is the content analysis by recording documents or archives that are closely related to the research objectives. The method of data collection by the author is to trace, analyze, and synthesize previous studies regarding learning to read Arabic letters and the Quran for the blind.

\section{RESULTS AND DISCUSSION}

\section{Understanding of Inclusive Education}

Inclusive Education is a system of providing education that provides opportunities for all students who have disabilities and have the potential intelligence or special talents to attend education or learning in an educational environment together with students in general. ${ }^{8}$ Inclusive education means that schools must accept or accommodate all

8 Ministry of National Education of Republik Indonesia, "Pendidikan Inklusif Bagi Peserta Didik Yang Memiliki Kelainan Dan Memiliki Potensi Kecerdasan Dan/Atau Bakat Istimewa", Minister of National Education Regulation No. 70/2009, 2009, article 1. 
children, without exception there are physical, intellectual, social, emotional, linguistic or other conditions, including children with and gifted children, street children, working children, children of ethnic, cultural, languages, minorities and disadvantaged and marginalized groups of children. This education program is what is meant by One School For All. ${ }^{9}$ Based on the derivative definition of the Law on Inclusion, children with special needs are those who have learning difficulties, children with learning disabilities, children with autistic disorders, children with mental disorders, children with physical and motor impairments, children with emotional and behavioral disorders, children with disabilities compound and talented child. According to Staub and Peck, there are five benefits or advantages of inclusive education, namely: first, loss of fear of non-the child with special needed children because they often interact with the child with special needed children, usually called Anak Berkebutuhan Khusus (ABK) in Indonesia, second, non-ABK children become more tolerant of others after understanding the individual needs of ABK friends, third, many non-ABK children who recognize an increase in self-esteem as a result of their association with $\mathrm{ABK}$, fourth, non-ABK children experience development and commitment to personal morals and ethical principles, fifth, non-ABK children who do not reject $\mathrm{ABK}$ say that they feel happy to be friends with $\mathrm{ABK} .{ }^{10}$

\section{Inclusive Education Model}

There are three types of inclusive education, namely: the first type is inclusive education. Inclusive education is an education in public schools that are tailored to the needs of students who need special education in public schools in a systemic unit. The curriculum used in inclusive education is a flexible curriculum that is tailored to the abilities and needs of each student. The second type is special education (or usually called in Indonesia Sekolah Luar Biasa or SLB). Special Education (SLB) is an educational institution that organizes educational programs for children with special needs. The third type is visiting the teacher. The visiting teacher model is carried out to equalize education for blind children of school age. This model is applied in the case that blind children cannot study in special schools or other schools because of difficult to reach homes,

\footnotetext{
${ }^{9}$ http://file.upi.edu/Directory/FIP/195412071981121, accessed 3 September 2019 at 06.00 WIB

${ }^{10}$ Staub, D. \& Peck, C.A, What are the Outcomes for Nondisabled Student?. Educational Leadership, 1995, p. 4.
} 
distance from schools and homes is too far, conditions for blind children who are unable to walk, suffer from suffering, and others.

\section{Blindness, Classification, and Characteristics}

Blindness is a condition of the child whose senses of vision or eyes do not function as a channel for receiving information in daily activities like a sighted person. ${ }^{11}$ Blind is a child who, for some reason, experiences a vision condition that is not functioning properly due to damage to the eye, optic nerve, and or the part of the brain that processes visual stimuli. ${ }^{12}$ Blind is a child who has vision problems and needs special needs. ${ }^{13}$ According to Hardman blind people in terms of blindness education (blindness) is a child who cannot use his vision and depend on other senses such as hearing, touch, this is called educationally blind. ${ }^{14}$

There are two kinds of blind people, namely total blindness and Low Vision. ${ }^{15}$ Total blindness can only capture light or light for mobility orientation. The total blind cannot use letters for learning other than Braille. While Low Vission can see weakly and blurred when objects are brought closer or far from his eyes. They use contact lenses or glasses.

Blind blinds are grouped in stages ranging from mild to severe. The weight and lightness are based on the ability to see the shadow of objects. Based on this ability, it can be grouped as follows: the first group is children who have vision problems that may be cured with certain drugs or optical devices. The second group is partially seeing childreen or mildly blind children are children who have vision impairment even though they have been treated and assisted by certain optical devices are still having difficulty learning in the regular class, so there is a need for compensatory learning compensation. ${ }^{16}$ The third group is children with severe blindness (blind) are blind people who can not be cured at all with any drug and optical devices. He can only learn with other senses. In The White

\footnotetext{
${ }^{11}$ Sutjihati Soemantri, Psikologi Anak Luar Biasa, (Bandung: Rafika Adittama, 2007), p. 65.

12 Sasraningrat, F. Harsana, Metodik Khusus Anak Tunanetra, (Yogyakarta: Indonesian Blind Welfare Federation, 1981), p. 7.

13 Direktorat Pendidikan Luar Biasa, tt. Alat Identifikasi Anak Berkebutuhan Khusus, (Department of Education and Culture), p. 5.

${ }^{14}$ Anastasia W dan Immanuel H, tt, Ortopedagogik Tunanetra I, (Department of Education and Culture), p. 5.

15 Aqila Smart, Anak Cacat Bukan Kiamat: Metode Pembelajaran dan Terapi Untuk Anak Berkebutuhan Khusus, (Yogyakarata Ar-Ruzz Media: 2010), p. 33.

${ }^{16}$ Muhammad Efendi, Pengantar Psikopedagogik Untuk Anak Berkelainan, (Jakarta: Bumi Aksara, 2006), p. 2.
} 
House Conference On Child Healty And Education in America, "people who cannot use their vision for education are called blind".

The characteristics of blind (blind) can be seen physical symptoms such as squinting eyes, often blinking, squinting, red eyes, red eyelids, eye infection, irregular and rapid eye movements, always watery eyes and swelling on the skin where eyelashes grow. ${ }^{17}$ Children with visual impairments sometimes overdo behavior such as excessive eye rubbing, closing or protecting one-sided eyes, difficulty reading, often avoiding work that requires excessive sense of sight. Bring the book closer to your eyes, frowning, clumsy in playing that requires cooperation between the hands and eyes.

For Low Vission usually write and read at close range, can only read large letters, look white in the middle of the eye (cataracts) or cornea looks foggy, looks do not look at the letters forward, squinting eyes in bright light, more difficult to see at night day, had had eye surgery or wore very thick glasses but still could not see clearly.

\section{Education for the Blind}

The blind have the right to get an appropriate education service like any other normal child. The governing guideline is Law of Republic Indonesia Number 20 of 2003 article 32 paragraph 1 which reads: "Special education is education for students who have difficulty in following the learning process because of physical, emotional, mental, and/or potential disabilities and special talents." 18

Human observations carried out by the eyes of approximately 85 percent. ${ }^{19}$ Therefore, to obtain information of a person who is blind, especially those who experience blind levels, will use non-visual vehicles that are still functioning such as hearing, tactile / tactual, odorless, and so on.

Children with visual impairments need special services to rehabilitate their disorders, which include: practice reading and writing Braille letters, use of sticks, orientation and mobility, and visual/functional vision training. Educational services for blind children can be carried out through the Segregation system, which is separately

\footnotetext{
17 Aqila Smart, Anak Cacat Bukan Kiamat: Metode Pembelajaran dan Terapi Untuk Anak Berkebutuhan Khusus, (Yogyakarata Ar-Ruzz Media: 2010), p. 37.

${ }^{18}$ Law of the Republic of Indonesia Number 20 of 2003. About the System Education \& Law Number 14 of 2005 concerning Teachers and Lecturers, (Jakarta: Visimedia, 2008), p. 16.

19 Sasraningrat \& Sumarno, Ortodidaktik Anak Tunanetra, (Jakarta: Department of Education and Culture RI, 1984).
} 
from alert children; and integration with integrated children in ordinary schools. Places of education with a segregation system, include special schools (SLB-A type), SDLB, and distant classes/visiting classes. Forms of cohesiveness that can be followed by blind children who follow the integration system include regular classes with consultant teachers, ordinary classes with visiting teachers, ordinary classes with resource rooms, and special classes.

Important elements in blind education are education personnel. Educational staff needed include teachers, psychologists, ophthalmologists, optometrists. Then the educational tools for the blind are divided into two parts, namely for full blind people and for low vision. For fully blind people, they include: first, special education tools. Specific educational tools include: Braille writing aids (reglets, pens, Braille typewriters, Braille printers, and abacus), keyboarding, calculation aids, Kurzweil reading machines, orientation training, and mobility. ${ }^{20}$ Second is aids and props. Assistive devices include touching aids (books, hot/cold water, and stones), hearing aids namely tapes, CDs, talking books, Braille reading aids (letterboards and options), assistive devices counting (logarithm, abacus or abacus, speech calculator), and audio aids such as tape-recorders. While the visual aids are tactual or audio aids are visual aids that can be observed through touching or hearing (animal sculptures, human body sculptures, arising maps). As for low vision educational aids are optical aids, including glasses, magnification goggles, hand magnifiers, assistive devices, including large lined paper, black markers, table lamps, the book supports, visual aids, pictures enlarged, preserved original objects, imitation models/statues. Aducational needs for the blind can be explained in the following table.

\section{Learning Arabic Literacy for the Blind}

Blind people need special learning activities in learning Arabic. In learning Arabic for beginners, both for the blind and not have to recognize letters hijaiyyah and harakat. The science that studies sound and sound in the realm of linguistics is called phonology; in Arabic, it is called Aswat. Studying hijaiyyah letters and harakat part of learning science Aswat. For the visually impaired aids to know hijaiyyah letters and harakat use Arabic Braille aids. The Arabic Braille writing system uses a dot pattern composed of 6

\footnotetext{
${ }^{20}$ J David Smith, Inklusi Sekolah Ramah Untuk Semua, (Bandung: Penerbit Nuansa, 2006), p. $245-251$.
} 
dots. ${ }^{21}$ Braille Arabic letters have the same function as ordinary Arabic script. The difference lies in the letters and how to read them. Each Arabic Braille letter will be represented by a different dot pattern (black), read from left to right. Stages in learning to read Arabic letters and the Quran Braille include: first stage is memorize the Arabic ي' Braille number codes starting from Alif أ until Ya

The second stage is memorize Arabic punctuation, such as: fathah, kasrah, dhammah, tanwin, and syiddah. The third stage is practically touching the Braille hijaiyyah letters and Arabic punctuation. The fourth stage is the IQRA reading practice starts from words to simple sentences. The fifth stage is the practice of reading the AlQuran, which starts from short letters to long letters. If in chart form, it can be seen in Figure 1.

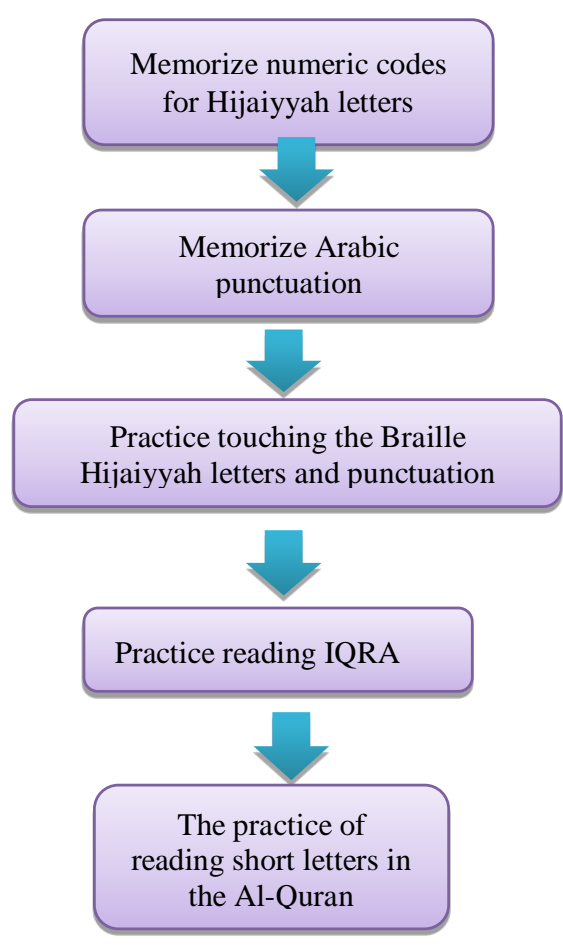

Figure 1

Stages of Learning Arabic Letters and Al-Quran

The sixth stage is to pay attention to the numeric codes of each letter, then memorize and practice reading by feeling for the blind. The examples of Arabic Braille letter can be seen in figure 2.

21 Ahmad Jaeni, "History of the Development of Braille Al-Qur'an in Indonesia From Duplication to Standardization (1964-1984)", Journal of SUHUF 8, no. 1, June 2015, p. 45-68. 


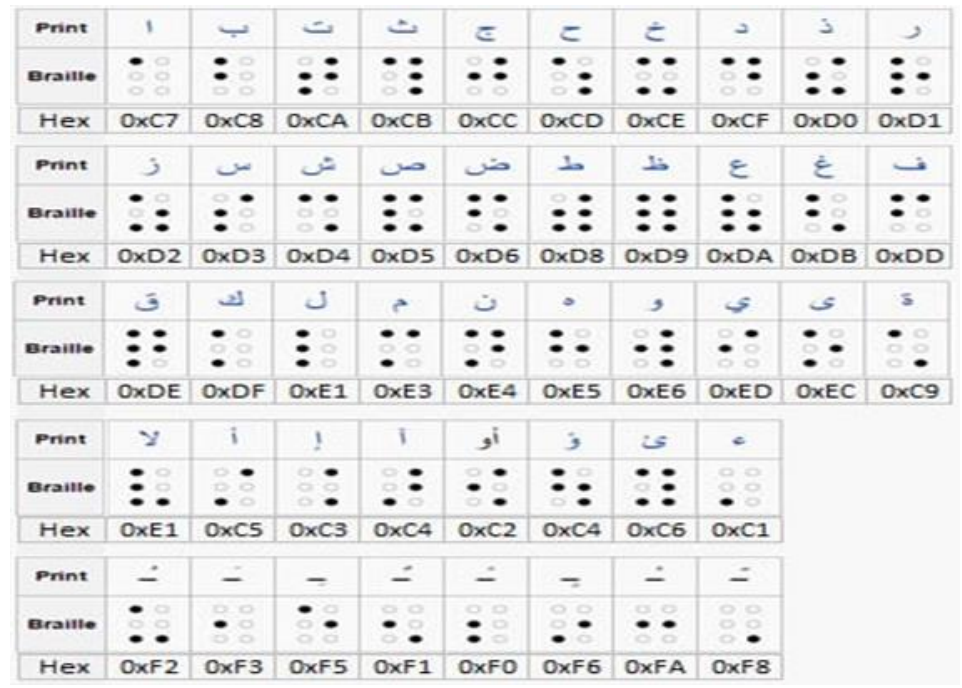

Figure 2

Examples of Arabic Braille Letters

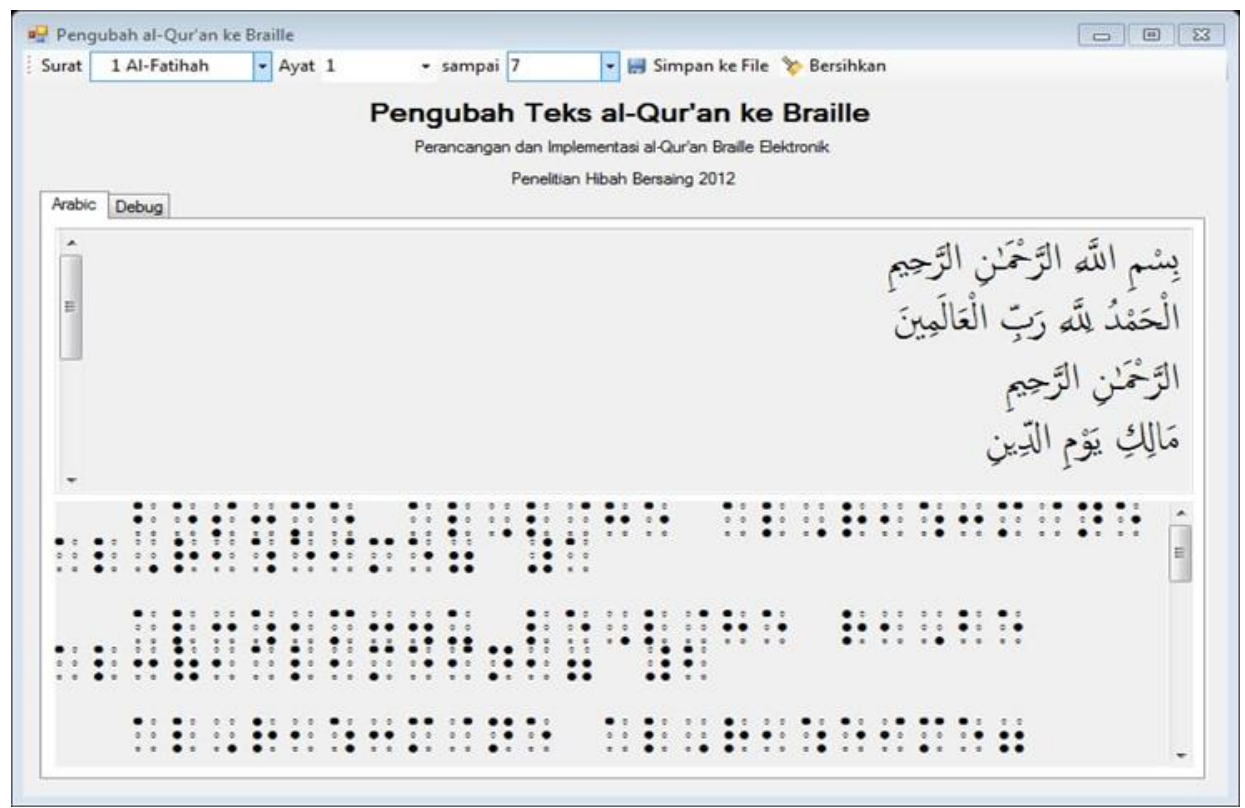

Figure 3

Hereinafter is An Example of A Fragment of Braille Alfatihah

Then, practice reading by touching from left to right, the opposite of his writing. Please note that when the letters above the hijaiyyah began to be arranged into words and sentences (Al-Fatihah letter) then surely there is a community that accompanies it as a vocal sign that makes a sound in Arabic letters. The trick is to try the letters first, then the community that accompanies it, and so on, to be continued and sequentially to the end.

\section{Blind Dynamics in Reading Arabic Letters Braille and the Qur'an}


Reading is a process of activities that involve physical and psychological. Physically relates to the sensory organs, namely the eyes and mouth, while the psychic relates to the process of thinking and speaking that is using cognitive intelligence (thinking) and linguistic intelligence (for speaking). Reading Arabic letters and the Koran is not an easy thing for the visually impaired, but also not a difficult thing the most important thing is the routine of practicing reading.

In the process of reading a blind person uses the physical sense of touch (hand) as a substitute for the sense of sight. In the process involving the brain as the center of thinking that uses intelligence and linguistic intelligence. Of course, this is not easy, but God is all-powerful, He can do everything by His power.

In fact, there are many blind and intelligent people who are skilled in reading Arabic letters and the Qur'an even today. Many are experts in technology and create digital Al-Qur'an. In an article, it was mentioned that the Digital Braille Al-Qur'an has appeared which helps the blind to be more practical in reading the Qur'an. ${ }^{22}$

\section{Educational and Learning Development Institutions Working in The World Of Visual Impairment}

Learning to read Arabic is a series of learning Quran. Until now, there are several methods of learning the Quran Braille that has been applied in various special education providers and blind foundation sponsors in several regions in Indonesia. The subject matter is also taken from various sources including Iqra ', al-Baghdady, Ummiy, Luqbah, Qira'ati, Sam' an, and so forth. Foundations and institutions that support blind people are: first, Yaketunis, Yogyakarta. This foundation uses the book "Qawaidul Imla" in the form of writing Braille Arabic letters written in 1967 by Fuady Aziz, then the book "How to Fast Learn Arabic Braille" compiled by Ahmad Maskuri, a blind person in Qiraat at Yaketunis, a graduate of UIN Sunan Kalijaga. Iqra Braille is Iqra Awas book that was braided. The "Ummi" method to practice smoothing and reading. The second institution is Sahabat Mata, Semarang: 10-hour Method ('Asyrah as-sa'ah). This method uses book material adopted from the al-Bagdadi and Qiraati methods in a simple form. Al-Bagdadi's method was adapted in using hijaiyah letters. Recognition of letters is done by

\footnotetext{
${ }^{22}$ Hamzah, Sholehudin Zaenal, "Quranic Technobraille: Towards the Blindness of Indonesian
} Blind-Free Muslims Read Al-Quran", Journal of Sociotechnology 11, no. 2, August 2018, p. 1-10. 
analysis/parsing technique, namely by mentioning the name of the letter and harakat so that it gives birth to the sound of reading. While the forms of training are adapted from the Qiraati method. While the forms of training are adapted from the Qiraati method. Initiated since 2008 by Ibn Abdillah. This method is designed for 10 lesson hours with ten meetings, it is expected that students master the introduction of Arabic Braille letters, and be able to read Braille codes in a series of words and sentences.

The third institution is Raudhatul Makfufin, South Tangerang: Iqra Braille is the first book created to assist teaching in reading exercises, but the initial concept is still delivered directly by the teacher so as not to confuse blind people. Then it was modified to be "The Book of Clever Reading of the Braille Quran" which is a book which is initially taught by the introduction of the Arabic Braille symbol, the Syaki sign, and the sequence in stages by adding reading exercises. The book "Knowledge of Tajweed", this book is adapted to the braille Quran writing system that discusses the letter makhraj, reading law, the nature of letters, and so forth.

The fourth foundation is Sam'an Foundation, Bandung: The Sami'an Method is an Arabic Braille guidebook consisting of 35 pages. Consists of four parts, namely: recognize letters hijaiyyah, sound, reading problems, and reading exercises. The fifth institution is YPAB Surabaya: A guide book for reading al-Quran Braille based on similarities and similarities in symbols composed by Zainul Muttaqin. Example: the letters alif, ba, ta, jim, dal, ro, za, sin, fa, qof, kaf, lam mim, nun, wau, ha, and yes, have exactly the same symbol as the letters: ab , t, j, d, r, z, s, f, q, k, l, m, n, w, h, and i. There are two Latin Braille letters adopted as Arabic letters, $\mathrm{v}$ and $\mathrm{x}$, which are lam alif and kho.

For blind people in Arabic language learners whose writing system is twisted and changed into a braille system into six points that arise, with different dots pattern to show the character of each letter. Likewise harakat is distinguished in the braille system in the form of six arising points. In teaching Arabic reading and writing, it usually uses a Reglet or a Stylus or a Perkins Braille typewriter. The first step taken when a child uses a reglet and stylus is to use a six-hole ruler and paper piercing nails commonly used for braille writing. After students are taught to write with these tools it will be easier to read. Writing using reglet and stylus teaches children to know letters and the location of dots on Braille letters. Teaching children to read while typing Braille through the Perkins typewriter will be much faster. 
Reglet is a ruler that has small holes lined up. When examined carefully, in the hole, there is a hole that is even smaller in size. The smallest range of holes are located vertically together. There are three vertical holes on the right-hand side and three vertical holes on the left. Bill is sorted, the small line of right-hand kana is numbered 1 to 3, and the small hole on the left is number 4 and 6 . The number numbers are used as a benchmark for writing the alphabet. For example, the letter A is written by punching holes in the cross-section of the paper in hole number 1. Then, writing the letter B is done by punching holes in the cross-section of the paper in holes number 1 and 2 . While the letter $\mathrm{C}$ by punching holes numbers 1,2 , and 4 . So that when touched, letter $\mathrm{A}$ is a dot, letter B is a long vertical point, and letter $\mathrm{C}$ is like an elbow.

Writing Braille is different from how you read it. Braille is written from right to left. While reading Braille is done like reading Roman letters in general, from left to right. The difference in how to read and write is what makes a little difficulty in learning blind people. In general, Reglets can keep Braille writing neat and straight. In Braille writing, a reglet is usually attached to the right end of a special paper. This paper is thicker than ordinary paper, so it is not hollow when written. A pair of reglets called a Stylus is a blunt toenail that has a handle at the other end. The size of the stylus is not as long as ordinary nails, but only as big as a thumb. The stylus is used to punch holes in the paper that has been clamped. Stylus pressure on the cross-section of the paper is what forms the new texture. For those who have difficulty using Braille due to several factors can use screen reader technology or digital books.

Braille is very useful for visually impaired people who mark certain items. Braille is the only media used in business cards. Sometimes, for some confidential documents, Braille is also used to maintain confidentiality. The Braille writing system was created by a Frenchman named Louis Braille. At the age of 4, Braille suffered blindness because his eye was pricked by a needle. Then he attended a special blind school. At that school, in 1921, Braille became acquainted with a French soldier named Charles Barbier. The army then introduced a military code-writing system that combined the location of 12 dots called "Night Writing" to Braille. Then Braille simplifies it into a combination of 6 dots. Not long after that, books were published which could then be read by the blind. 


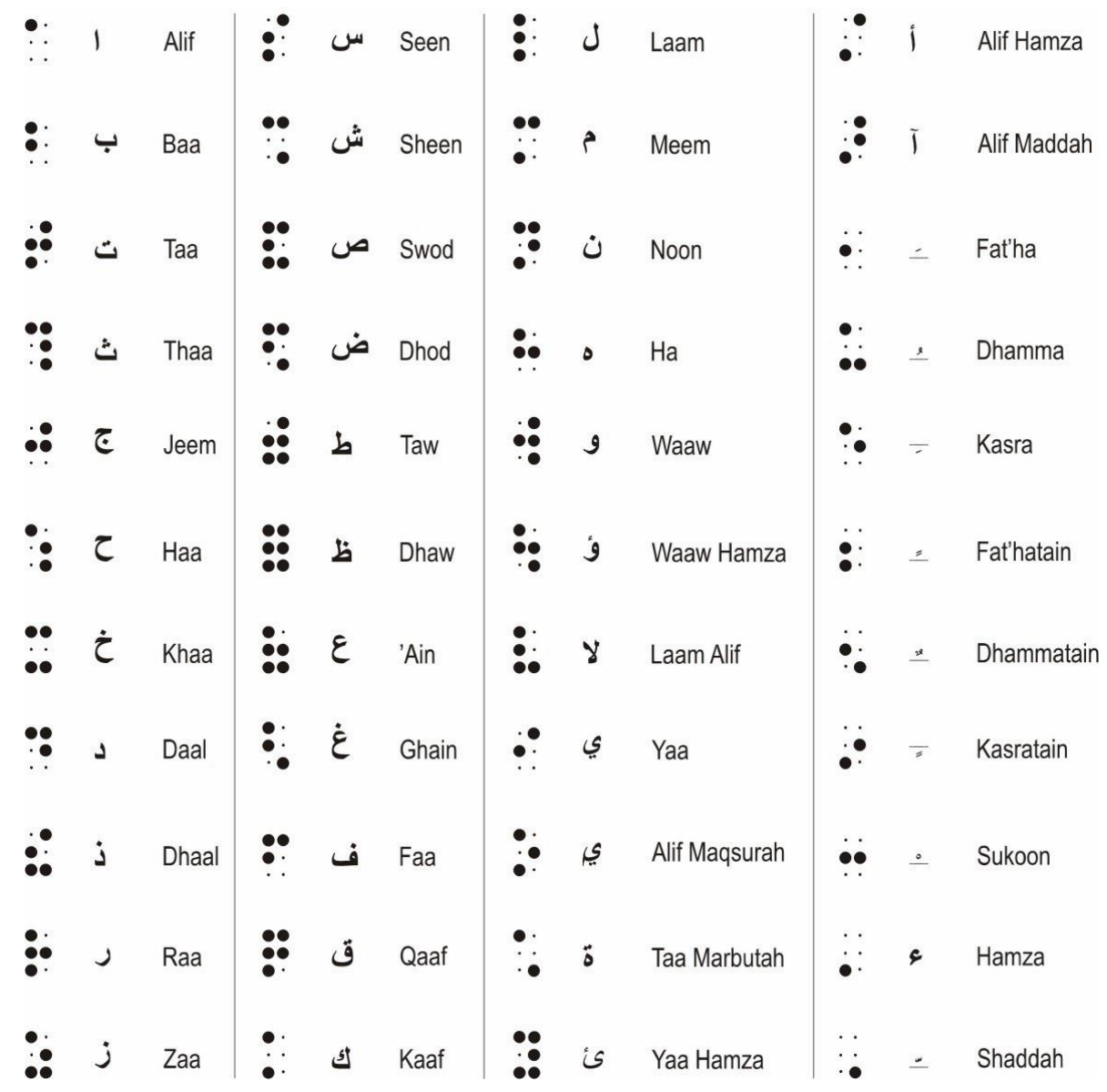

Figure 4

Arabic Braille Letter

The way the teacher teaches: based on the author's observations of the way the teacher teaches reading the Arabic Braille letters are: the first, the teacher prepares the material to be learned, which is maqro '/ reading material that has been copied into the Braille letter. Besides, the teacher prepares instruments that have been made by researchers. The instrument is used by teachers to assess the readings of students studied. The second is the teacher gave the opening greetings. The third is the teacher submits Braille reading material to students. The fourth is the teacher tells students to read the Maqro 'Braille. The fifth is the teacher also explains the subject matter that has not been mastered by students. The sixth is the teacher listens to the students' reading/research subjects from word to sentence, sentence by sentence, to completion. The eighth is the teacher records the maqro that has been learned on the card. The ninth is achievement and writing in the student reading indicator instrument. The tenth is the teacher makes a decision on 
the reading assessment results to determine the Final Decision, namely: continue reading the next or still repeat. The eleventh is the teacher asks students to read back the maqro that they have learned at home. The twelfth is the teacher also gives a compliment if the student reading is correct and reminds if something goes wrong.

\section{CONCLUSION}

Education for the visually impaired must be considered because it is regulated in the law. Blind education takes the form of classroom learning, both managed by the government and the private sector. Aids to read Arabic letters and Quran for the visually impaired using Arabic letters and Quran Braille. Stages Learning to read Arabic writing in the form of learning to read Arabic letters and the Koran for the visually impaired are: stages of Learning Arabic letters and the Quran, memorize numeric codes for Hijaiyyah letters, memorize Arabic punctuation, practice touching the Hijaiyyah Braille letters and punctuation marks, practice reading IQRA, practice reading short letters in the Quran.

\section{REFERENCES}

Aziz, Fuadi. (1978). "History of the Writing of Al-Quran Braille in Indonesia", Proyek was delivered to Muker IV of the Braille Ulema on March 15-16, 1978 at Ciawi Bogor.

Directorate of Special Education, tt. Alat Identifikasi Anak Berkebutuhan Khusus, (Jakarta: Department of Education and Culture).

D. Staub \& Peck, C.A. (1995). What are the Outcomes for Nondisabled Student?.(New Jersey: Educational Leadership).

Efendi, Muhammad. (2006). Pengantar Psikopedagogik Untuk Anak Berkelainan, (Jakarta: Bumi Aksara).

Hamzah \& Sholehudin Zaenal. (2018). "Quranic Technobraille: Towards the Blindness of Indonesian Blind-Free Muslims Read Al-Quran", Journal of Sociotechnology 11, no. 2, p. 1-10.

Harsana, Sasraningrat F. (1981). Metodik Khusus Anak Tunanetra. (Yogyakarta: Indonesian Blind Welfare Federation).

https://www.cendananews.com/2017/04/juta-tuna-netra-di-indonesia-belum-dapatakses-pend Pendidikan.html, accessed on 3 September 2019 at 11:00. 
http://file.upi.edu/Directory/FIP/195412071981121, accessed 3 September 2019 at 06.00 $\underline{\text { WIB }}$

Jaeni, Ahmad. (2015). "History of the Development of Braille Al-Qur'an in Indonesia From Duplication to Standardization (1964-1984)", Journal of SUHUF 8, no. 1, p. 45-68.

Law of the Republic of Indonesia Number 20 of 2003. (2008). About the System Education \& Law Number 14 of 2005 concerning Teachers and Lecturers, (Jakarta: Visimedia).

Ministry of National Education of Republik Indonesia. (2009). "Pendidikan Inklusif Bagi Peserta Didik Yang Memiliki Kelainan Dan Memiliki Potensi Kecerdasan Dan/Atau Bakat Istimewa", Minister of National Education Regulation No. 70/2009.

Rasikhin, H.R. (1977). "Looking for the Braille Arabic Letter Formulation for Writing Braille Al-Quran That Is Closest to the Writing of Al-Quran Awas", in the Documentation of the Third Work Conference of Braille Al-Quran Ulama, (Jakarta: Department of Religion RI), p. 11.

Research Center for Religious Literature. (1978). Religion Research and Development Agency. Results of the Fourth Deliberation of Al-Quran Ulama Work, (Jakarta: Ministry of Religion of the Republic of Indonesia).

Sasraningrat \& Sumarno. (1984). Ortodidaktik Anak Tunanetra, (Jakarta: Department of Education and Culture of Republic Indonesia).

Singh, JD. (2016). "Inclusive Education In India - Concept, Need And Challenges", An International Peer Reveiwed and refered, Scholarly Research Journal For Humanity Science and English Language (SRJIS) 3, P. 3224.

Smart, Aqila. (2010). Anak Cacat Bukan Kiamat: Metode Pembelajaran dan Terapi Untuk Anak Berkebutuhan Khusus, (Yogyakarata Ar-Ruzz Media).

Smart, Aqila. (2010). Anak Cacat Bukan Kiamat: Metode Pembelajaran dan Terapi Untuk Anak Berkebutuhan Khusus, (Yogyakarata Ar-Ruzz Media).

Smith, J David. (2006). Inklusi Sekolah Ramah Untuk Semua, (Bandung: Penerbit Nuansa).

Soemantri, Sutjihati. (2007). Psikologi Anak Luar Biasa, (Bandung: Rafika Adittama).

UNICEF. (2007). Promoting the Rights of Children with Disabilities.Innocenti Research Centre. Retrieved from http://www.unicef-irc.org/publications/pdf/digest13disability.pdf on September 2019.

W Anastasia \& Immanuel H, tt, Ortopedagogik Tunanetra I, (Jakarta: Department of Education and Culture). 